\title{
Accounting and Finance Review
}

Journal homepage: www.gatrenterprise.com/GATRJournals/afr_issues.html

Acc. Fin. Review 4 (4) 96 - 105 (2019)

\section{The Relationship among Media Exposure, Taxes Aggressiveness, and Corporate Governance on CSR Disclosure}

\author{
Agustin Palupi \\ ${ }^{1}$ Trisakti School of Management Jakarta, Indonesia
}

\begin{abstract}
Objective - Corporate social responsibility disclosure (CSRD) is an interesting issue, which has an influence on the decision of an investor when deciding whether to invest in a company. This study examines the empirical evidence about the factors which influence CSRD. The factors include media exposure, taxes aggressiveness, and corporate governance.

Methodology/Technique - This study uses companies listed in the non-financial sector on the Indonesian Stock Exchange between 2014-2016. There are 64 companies that meet these criteria using a purposive sampling method.

Findings - The results show that media exposure, taxes aggressiveness, institutional ownership, independent commissioner, and firm size have an influence on corporate social responsibility disclosure. Firm age, leverage, profitability, liquidity, and managerial ownership have no influence toward corporate social responsibility disclosure.

Type of Paper: Empirical
\end{abstract}

Keywords: Corporate Social Responsibility; Media Exposure; Taxes Aggressiveness; Firm Age; Leverage; Profitability; Liquidity; Institutional Ownership; Managerial Ownership; Independent Commissioner.

Reference to this paper should be made as follows: Palupi, A; (2019). The Relationship among Media Exposure, Taxes Aggressiveness, and Corporate Governance on CSR Disclosure, Acc. Fin. Review, 4 (4): 96 - 105 https://doi.org/10.35609/afr.2019.4.4(1)

\section{JEL Classification:}

\section{Introduction}

Corporate social responsibility (CSR) is an idea that makes companies no longer faced with responsibilities that are grounded in a single bottom line. Corporate responsibility must be based on triple bottom lines which also takes into account to social and environmental problems (Daniri, 2008). Triple bottom line reporting is a report that provides information on the implementation of economic, social and environmental activities of an entity. If the principle of triple bottom line reporting is implemented properly, it will show that corporate accountability is not only for the implementation of their economic activities, but also for the implementation of social and environmental activities (Deegan, 2004).

* Paper info: Revised: October 15, 2019

Accepted: December 31, 2019

* Corresponding author: Agustin Palupi

E-mail: mahasiswapoppy@gmail.com

Affiliation: Accounting, Trisakti School of Management, Indonesia 
Thus, the principle of triple bottom line reporting can accommodate stakeholder interests broadly, not only the interests of shareholders and bondholders.

Financial information obtained through financial statements and non-financial information can be obtained through CSR (Corporate Social Responsibility), which includes information on employees, consumers, communities and the environment. According to Dewi and Keni (2013), positive impacts of the company's activities include creating employment opportunities, producing public needs and others. On the other hand, the company's activities also have the potential to damage the environment such as pollution, disasters, exploitation of natural resources and labour which will ultimately interfere with survival. Competition in the business and economic world is increasingly complex and has experienced growth. The main goal of a company is to maximize prosperity and profits for its shareholders (Brigham \& Houston 2006).

In Indonesia, CSR reporting has started to grow, with the government regulation stipulated in Government Act No. 47 of 2012 on social and environmental responsibility of limited companies and limited company law (UUPT) expected to be more transparent. The purpose of this study is to obtain empirical evidence about the factors which influence corporate social responsibility disclosure. Those factors include media exposure, taxes aggressiveness, corporate governance, firm age, firm size, leverage, profitability, and liquidity.

Although regulations have been established governing CSR implementation and reporting, these regulations do not provide specific guidelines on how and what information companies must report regarding CSR implementation, meaning that adequate disclosure related to CSR activities is still lacking. So far, the disclosure of CSR activities is based only on the company's need to form that image in the view of the company's stakeholders who have a concern for the social environment and economic environment (Gray, Kouhy \& Lavers, 1995).

Reverte (2009) conducted a study of 46 companies listed on the Spanish stock exchange in 2008. That research used 7 variables: company size, industry sensitivity, profitability, ownership structure, media exposure, international listings, and leverage. The results show that company size, industry sensitivity and media exposure had a positive effect on the company's CSR disclosure. Meanwhile the company's profitability, ownership structure, international listings and leverage did not have a significant effect on CSR disclosure indexes.

Management efforts designed to aggressively minimize tax burdens are a common phenomenon throughout the country. Tax aggressiveness can be defined as all efforts made by management to reduce the amount of tax burden the company is required to pay (Lanis \& Richardson, 2013). Meanwhile, Frank, Lynch and Rego (2009) define tax aggressiveness as an act of manipulating taxable income that is designed through tax planning actions using both legal (tax avoidance) and illegal (tax evasion) methods.

According to Belkaoui and Karpik (1989), companies disclose social information in order to build an image of the company and to gain the positive attention of the public. Companies need costs in order to provide social information, so that the reported profits in the current year will be lower. However, due to the lack of supervision in the company's supervisory system, managers can easily take earnings management actions with interventions in the preparation of financial statements based on accrual accounting, therefore a corporate governance application is expected to improve earnings quality through oversight of the financial reporting process and the implementation of external audits.

Belkaoui (1989) found (1) social disclosure has a positive relationship with corporate social performance, meaning that companies are carrying out social activities to express it in social reports, (2) there is positive relationship between social disclosure and political visibility, where large companies that tend to be monitored will disclose more information social compared to small companies, (3) there is a negative relationship between disclosure social with the level of financial leverage. Agency theory predicts that companies with higher leverage ratios will reveal more information, because of agency costs companies with such capital structures are higher (Jensen \& Meckling, 1976). This study aims to examine CSRD influenced 
by media disclosure, tax aggressiveness, and corporate governance. This research was conducted on companies published on the Indonesian Stock Exchange between 2014-2016.

\section{Literature Review}

\subsection{Agency Theory}

Agency theory is used to understand the concept of GCG. Jensen and Meckling (1976) say that the agency relationship is a contractual relationship between the investor (principal) and the manager (agent). The authority and responsibilities of the agent and the principal are regulated in a work contract with mutual agreement. In reality, principals and agents have different interests, resulting in a conflict of interest between the owner and the agent that triggers agency costs.

Agency problems arise because the contract between the agent and the principal in every action taken by the agent as a party that has more information at the time of decision making is often thought to improve not only his own welfare but also the welfare of the principal (Brennan, 1995). Differences in information between management and principals can provide managers with opportunities to manage earnings through CSRD which can mislead principals and users of financial statements about the company's economic performance. According to Richardson (1998), there is a positive relationship between information asymmetry and earnings management. This means that if managers have more information than shareholders, the manager's tendency to cheat with earnings management practices for his personal interests will be even higher.

\subsection{Stakeholder Theory}

Stakeholder theory states that companies support entities that only serve their own interests, having broader goals, with serving by creating value for stakeholders. This theory assumes the existence of the company is determined by the stakeholders and the company concerned and responds to stakeholders needs (Ginting, 2016).

Herawati (2015) states that stakeholders are all parties, both internal and external who have a relationship, which is influential or influenced, either directly or indirectly, by the company. Thus, stakeholders are internal and external parties, such as governments, competing companies, surrounding communities, the international environment, institutions outside the company (NGOs), company workers, environmental observers, etc. whose existence greatly influences and is influenced by the company. With the presence of a number of stakeholders, the company is required to disclose corporate social responsibility which is used as a tool to manage organizational relationships with different stakeholder groups because the company's main goal is to balance conflicts between stakeholders.

\subsection{The Legitimacy Theory}

The theory of legitimacy is based on the notion of a social contract that is implied between social institutions and society. The legitimacy theory explicitly recognizes that business is limited by social contracts stating that the company agrees to show a variety of corporate social activities so that the company obtains community acceptance of the company's goals which will ultimately guarantee the survival of the company (Reverte, 2009). Corporate activities have social and environmental impacts, CSR disclosure practices are a tool used by companies to avoid social and environmental conflicts. In addition, the practice of social and environmental disclosure can be seen as a form of corporate accountability to the public to explain the various social and environmental impacts caused by the company, both good and bad.

Management of the company needs the support of a conducive community environment. In other words, companies need legitimacy from the surrounding community. This is in line with the legitimacy theory which 
states that the company has a contract with the community to carry out its activities based on the values of justice, and how the company responds to various interest groups to legitimizes the company's actions (Tilt, 1994, in Haniffa \& Cooke, 2005). If there is an inconsistency between the company's value system and the community value system, the company can lose its legitimacy, which in turn will threaten the survival of the company (Lindblom, 1994, in Haniffa et. al., 2005).

\subsection{Corporate Social Responsibility Disclosure (CSRD)}

Corporate activities have social and environmental impacts. CSR disclosure practices are a tool used by companies to avoid social and environmental conflicts. In addition, the practice of social and environmental disclosure can be seen as a form of corporate accountability to the public to explain the various social and environmental impacts caused by the company, both good and bad. CSRD is described as financial and nonfinancial information relating to social organizations with their environment and social (Santioso \& Devona, 2012). The aim of CSR is to create a higher standard of living, by maintaining the sustainability of operating profit for stakeholders as disclosed on financial statements (Kamil \& Herusetya 2012). CSR disclosure standards in Indonesia refer to the standards developed by GRI (Global Reporting Initiatives).

\subsection{Hypothesis Development}

\subsubsection{The Effect of Media Exposure On CSRD}

Media exposure is company action to provide information about its social responsibilities and other related messages to employees, customers and other stakeholders, and in general, to the whole community. Plorensia and Hardiningsih (2015) state that communicating CSRD through the media will enhance the company's reputation in the public view and is important in disclosing corporate social responsibility. With the disclosure of CSR through public media can find out social activities carried out by the company. Plorensia and Hardiningsih (2015) obtained empirical evidence that media disclosure has an influence on disclosure of corporate social responsibility.

In the current era of globalization, companies disclose corporate social responsibility activities through various media outlets. Media is at the centre of public attention about a company (Yao, et. al., 2011). Internet media (web) is an effective form of media because internet users are always increasing. News about social responsibility in this era will spread even faster with the company's website (page). By communicating corporate social responsibility through internet media, it is expected that the public will know the social activities carried out by the company. Communication of CSR through the media will enhance the company's reputation in the public's view. The communication of corporate social responsibility will improve the company's image and reputation in the eyes of the surrounding community.

Research conducted by Plorensia and Hardiningsih (2015) is not consistent with Dermawan and Deitiana (2014). Dermawan and Deitiana (2014) state that media disclosure has no influence on disclosure of corporate social responsibility. Plorensia and Hardiningsih (2015) on the other hand state that communicating CSR through the media will increase a company's reputation so being important disclosing corporate social responsibility. Therefore, CSR disclosure through media can increase awareness of the social activities carried out by the company. Dermawan and Deitiana (2014) show that Media Exposure does not significantly effect CSR disclosure. Based on the description above, the first hypothesis that will be tested in this study is:

Ha1: Media Exposure has a positive effect on CSRD. 


\subsubsection{The Effect of Taxes Aggressiveness On CSRD}

Plorensia and Hardiningsih (2015) stated that tax aggressiveness action aims to minimize corporate tax which is now a public concern because it is not in line with public expectations and is also detrimental to the government. Companies with high tax aggressiveness tend to disclose more social responsibility information. This is a tactic to obtain the trust of the public and the tax burden that should be issued will be transferred to the burden of CSR.

The relationship between tax aggressiveness and corporate social responsibility disclosure was identified by Plorensia and Hardiningsih (2015). Tax aggressiveness has an influence on disclosure of corporate social responsibility. Companies that are aggressive towards taxes will disclose more corporate social responsibility information because the corporate tax burden that should have been issued to social responsibility activities (Plorensia \& Hardiningsih, 2015). The research conducted by Plorensia and Hardiningsih (2015) is consistent with research conducted by Lanis and Richardson (2013), which also found evidence that tax aggressiveness affects the disclosure of corporate social responsibility.

When companies carry out their operations, they must pay attention to all internal and external parties of the company. Companies that are aggressive towards taxes will tend to disclose additional information related to their corporate social responsibility activities in various fields, which are intended to attract the attention of the public and seek their sympathy. The higher the tax aggressiveness actions, the more the disclosure of corporate social responsibility will be maximized. Therefore, the following hypothesis is proposed:

Ha2: $\quad$ Taxes aggressiveness has a negative effect on CSRD.

\section{The Effect of Corporate Governance On CSRD}

\subsubsection{Institutional Ownership and Corporate Social Responsibility Disclosure}

According to Budiman (2015), institutional ownership is share ownership by parties in the form of institutions, such as foundations, banks, insurance companies, investment companies, pension funds, companies in the form of Limited Liability Companies (PT), and other institutions. Institutions that invest their capital in other companies consider the issue of social responsibility as a criterion when investing. As is ownership within the company, institutional investors have power to be responsible for implementing the principles of Corporate Governance intended to protect the rights and interests of all shareholders. Thus, institutional ownership can increase the quality and quantity of voluntary disclosures that result in companies being required to increase their social responsibility disclosures (Ramdhaningsih \& Utama, 2013). Hence, with greater institutional ownership, the implementation of corporate governance will increase. Budiman (2015), Rahayu and Rahayu (2013), Sari and Rani (2015), and Ramdhaningsih and Utama (2013) conclude that institutional ownership has a negative effect on CSR disclosure. However, Herawati (2015) and Ginting (2016) conclude that institutional ownership does not affect CSR disclosure. The following hypothesis is proposed:

\section{Ha3: Institutional ownership has a negative effect on CSRD.}

\section{Managerial Ownership and CSRD}

Managerial ownership refers to the percentage of share ownership in the management of the company (Ramdhaningsih \& Utama, 2013). The ownership of management in a company will increase the value of the company as a result of increased management ownership. A high level of management ownership tends to 
persist, where management can carry out social responsibility programs easily. Therefore, the higher the level of managerial ownership, the higher the level of corporate social responsibility activities. According to Ramdhaningsih and Utama (2013), Prakarsa and Astika (2017), Pasaribu et. al. (2015), and Ginting (2016), managerial ownership has a positive on CSR disclosure. However, Sari and Rani (2015) and Kurniawan (2014) conclude that managerial ownership does not affect CSR disclosure.

Conflicts of interest between managers and owners become even greater when managerial ownership is reduced (Jensen \& Meckling, 1976). In this case, the manager will try to maximize their own interests instead of the interests of the company. The following hypothesis is proposed:

\section{Ha4: Managerial Ownership has a positive effect on CSRD.}

\section{Independent Board and CSRD}

Independent commissioners are members of the board of commissioners who are not included on the board of directors, other members of the board of commissioners and controlling shareholders. Independent commissioners are also free from business relationships or other relationships that can affect their ability to be independent. Board of commissioners from outside the company are considered better because they will establish policies relating to the company objectively compared to companies that have a board of commissioners composed mainly of directors from within the company (Sulistyawati et. al., 2016).

Haniffa and Cooke (2002) state that the more independent commissioners in a company, the more power the board of commissioners has to pressure management to improve the quality of company information disclosure. The greater composition of the independent board of commissioners can encourage the board of commissioners to act objectively and be able to protect all company stakeholders so it can encourage CSR disclosure. Independent commissioners are needed to increase the independence of the board of commissioners towards the interests of shareholders and really put the interests of the company above other interests (Muntoro, 2006).

In the IDX regulations, it is stated that the listed company must have an independent commissioner not affiliated with the company and the amount is at least $30 \%$ of the total board of commissioners. The existence of independent commissioners will further strengthen the supervision of the board of commissioners because it is not affiliated with the company. Thus, with more independent commissioners in a company, it will expand its social responsibility disclosure. Sulistyawati et. al. (2016), Primadewi and Mertha (2014), and Ginting (2016) conclude that independent board members have an effect on CSR disclosure. However, Ramdhaningsih and Utama (2013), Herawati (2015), and Kurniawan (2014) conclude that it does not affect CSR disclosure. The following hypothesis is proposed:

Ha5: Independent board members have a negative effect on Corporate Social Responsibility disclosure.

\section{Research Methodology}

\subsection{Variables Definitions}

\subsubsection{Dependent Variable}

Corporate social responsibility is important for the company because the company is managed in the community environment and its activities can improve social relations and the environment (Ghozali \& Chariri, 2014). Disclosure of corporate social responsibility is a managerial tool used to avoid social and environmental conflicts. Disclosure of corporate social responsibility can also facilitate stakeholders' interests. Disclosure of Corporate Social Responsibility as the dependent variable in this study is measured by an index used by Sembiring (2005) with 78 disclosure items. 


\subsubsection{Independent Variables}

There are 10 independent variables. Media exposure is measured by a dummy variable, which will be assigned a value of " 1 " if there is disclose of CSR activities on company website and a value of " 0 " otherwise (Plorensia \& Hardiningsih 2015). Taxes aggressiveness is measured by ETR with income tax expenses divided by income before tax (Plorensia \& Hardiningsih, 2015).

The proxies of corporate governance are institutional ownership, managerial ownership, and independent commissioners. Institutional ownership is measured by the percentage of institutional ownership which includes banks, pension, insurance companies, incorporated and other financial institutions (Herawati, 2015). Managerial Ownership is measured by the number of shares owned by management divided by the outstanding shares (Sari \& Rani, 2015). Independent board is measured by the percentage of independent commissioners in the company (Sulistyawati et. al., 2016).

The research model also includes some control variables. Profitability is measured by return on equity (Wasito et. al., 2016). Liquidity is measured by current ratio which is current assets divided current liabilities (Wasito et. al., 2016). Leverage is measured by Debt to Equity Ratio (Dewi \& Keni, 2013). Company Size is measured by the natural logarithm of the total assets owned by the company (Dewi \& Keni, 2013). Firm Age is measured by the length of time a company is listed on the Indonesia Stock Exchange starting from the Initial Public Offering (IPO).

\section{Results}

This paper's research examined 192 non-financial firms listed on the Indonesian Stock Exchange between 2014-2016. Furthermore, the entire sample is further classified into 148 companies $(77,15 \%)$ that do not disclose CSR on their media whereas 44 companies $(22,0 \%)$ did.

Based on Table 1, it can be seen that media exposure has a regression coefficient 0.069 and a significant value of 0.001 . From these results it can be concluded that Hal is accepted, or media exposure positively affects CSR disclosure. Media exposure can increase CSR disclosure. Communicating CSR on media will increase the company's image and reputation, which is consistent with stakeholder theory.

Tax aggressiveness (ETR) has a regression coefficient of -0.025 and a significant value of 0.043 which is less than 0.05. From these results it can be concluded that Ha2 is accepted, or Tax Aggressiveness negatively affects CSR disclosure. The lower the value of ETR, the higher the level of tax aggressiveness of a company and the broader the company will be in expressing its social responsibility.

Institutional ownership has a regression coefficient of -0.085 and a significant value of 0.019 which is less than 0.05. This is the same with Independence Board with a regression coefficient of -0.355 and a significant value of 0.000 . From these results it can be concluded that $\mathrm{Ha} 3$ and $\mathrm{Ha} 5$ are accepted. Institutional ownership and independent board negatively affect CSR disclosure. If the company has more institutional ownership and an independent board, the company will publish reduced levels of information about CSR. Managerial ownership has a regression coefficient of -0.092 and a significant value of 0.322 which is more than 0.10 . Therefore, Ha4 is rejected. Managerial ownership does not affect CSR disclosure. Furthermore, Leverage negatively affects CSR disclosure. Company size positively affects CSR disclosure. Profitability, Liquidity, and Firm Age do not affect CSR disclosure. 
Table. 1: Corporate Social Responsibility

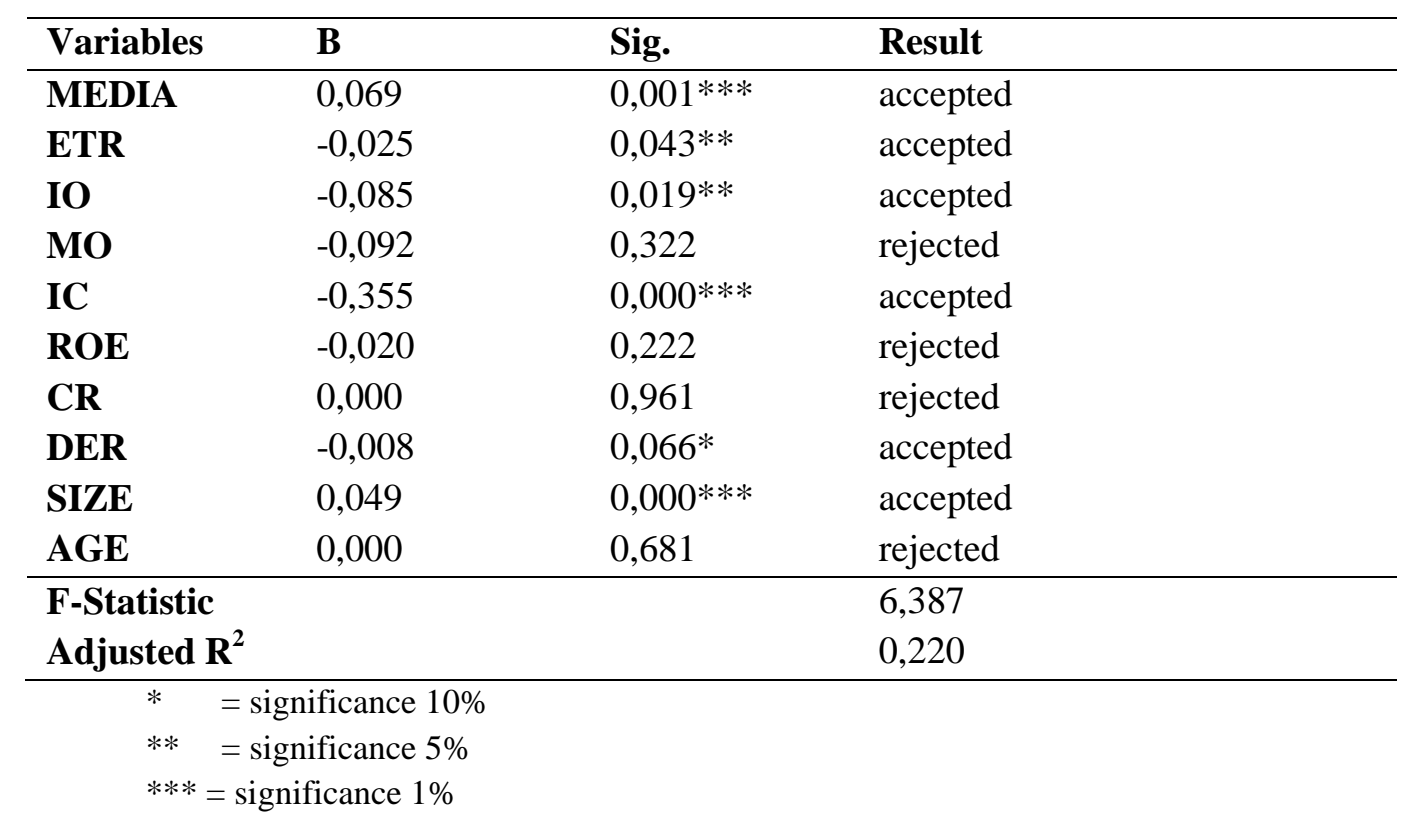

\section{Discussion}

Media exposure can increase CSR disclosure. Websites allow electronic dialogue among companies, owners and stakeholders and are also a source of environmental information. By communicating CSR through a company website, it is expected that the public will know about the social activities carried out by the company. Communication of CSR through media will enhance the company's reputation in the public view. Media also plays an active role by providing a reporting history and compiling it to illustrate the value of a company. Thus, the media indirectly affects the survival of the company. Therefore, companies that have a corporate website will be more likely to disclose their CSR activities widely.

Tax Aggressiveness is measured by ETR to show that the lower value of ETR, the more ineffective the tax rate for the company. This means that the level of tax aggressiveness of a company will increase thereby causing the company become more widespread in expressing its social responsibility. These results explain that the more CSR activities the company carries out, the higher the attitude of responsibility owned which is reflected in its adherence to paying the amount of tax burden that has been set or it can be concluded that the company is less aggressive towards taxes. The results of this study support the theory of legitimacy which explains that the disclosure of social responsibility by the company to get legitimacy from the community where the company is located. This legitimacy causes the company to avoid things that are not desirable and can increase the value of the company. The legitimacy theory states that organizations not only pay attention to investor' rights but also pay attention to public rights (Brown \& Deegan, 1998).

Institutional ownership negatively affects CSR disclosure. If the company has more institutional ownership and an independent board, the company will reduce the information about CSR that is made publicly available. CSR disclosure is not influenced by managerial ownership. Because they reveal CSR as a form of environmental responsibility for users of financial statements. In general, large companies will disclose more information than small companies. This aims to reduce agency costs that should have been incurred. If companies have large assets, large sales, sophisticated information systems, many types of products, as well as good employee skills, they require a broad level of disclosure. The higher the level of debt, the less the company will reveal the level of CSR. Furthermore, companies will not consider how much 
profit they will get, liquidity or even age to be able to disclose their CSR. CSR means communication and establishing good relationships between the company and the environment.

\section{Conclusion}

Based on the results of the hypothesis testing, it can be concluded that media exposure has a positive influence on CSR disclosure. Tax aggressiveness negatively affects CSR disclosure. The lower the value of ETR, the higher the level of tax aggressiveness of a company and the broader the company will be in expressing its social responsibility. Institutional ownership, independent commissioner, leverage and company size have a negative effect on CSR disclosure. Managerial ownership, liquidity, and firm age do not have a significant impact on CSR disclosure.

There are limitations to this study. This research only examines a three-year period and the variables used are limited. Future research should increase the research time and include additional variables that may have an effect on CSR, such as other proxies of corporate governance and the industry sector. To calculate CSR, CSR disclosure can be separated into each category or other reporting methods can be used, such as sustainability reporting.

\section{References}

A.P., Winda Plorensia, and Pancawati Hardingsih. 2015. The Effect of Tax Aggressiveness and Media Exposure on Corporate Social Responsibility. Dynamics of Accounting, Finance, and Banking, Vol. 4, No. 2: 136-151.

Belkaoui, A., \& Karpik, P. G. (1989). Determinants of the corporate decision to disclose social information. Accounting, Auditing \& Accountability Journal, 2(1). https://doi.org/10.1108/09513578910132240

Budiman, N. A. (2015). Factors That Influence Corporate Social Responsibility Disclosure. Journal of Mercu Buana Accounting Research, 1 (1), 14-34. http://ejurnal.mercubuana-yogya.ac.id/index.php/akuntansi/article/download/9/6

Brigham, Eugene F. dan Houston, Joel F. 2006. Fundamental of Financial Management. Jakarta: Salemba Empat.

Brown, N., \& Deegan, C. (1998). The public disclosure of environmental performance information-a dual test of media agenda setting theory and legitimacy theory. Accounting and business research, 29(1), 21-41. https://doi.org/10.1080/00014788.1998.9729564

Daniri, A. (2010). Accountability, Needs, Reporting and CSR Disclosures for Companies in Indonesia. Akuntan Indonesia, 12.

Deegan, C. (2004). Financial Accounting Theory. Australia: McGraw-Hill.

Generous, Decky, and Tita Deitiana. 2014. Factors Affecting Corporate Social Responsibility Disclosure. Journal of Business and Accounting, Vol. 16, No. 2: 158-165.

Dewi, Sofia Prima dan Keni. 2013. The Effect of Company Age, Profitability, Company Size, and Leverage on Corporate Social Responsibility Disclosure. Jurnal Bisnis dan Akuntansi, Vol. 15, No. 1: 1-12.

Frank, M., Lynch, L., \& Rego, S. (2009). Are financial and tax reporting aggressiveness reflective of broader corporate policies. The Accounting Review, 84(2), 467-498.

Haniffa, R. M., \& Cooke, T. E. (2002). Culture, corporate governance and disclosure in Malaysian corporations. Abacus, 38(3), 317-349. https://doi.org/10.1111/1467-6281.00112

Jensen, M. C., \& Meckling, W. H. (1976). Theory of the firm: Managerial behavior, agency costs and ownership structure. Journal of financial economics, 3(4), 305-360. https://doi.org/10.1016/0304-405X(76)90026-X

Gray, R., Kouhy, R., \& Lavers, S. (1995). Constructing a research database of social and environmental reporting by UK companies. Accounting, Auditing \& Accountability Journal, 8(2), 78-101. https://doi.org/10.1108/09513579510086812

Ginting, Y. L. (2016). Governance mechanisms and disclosure of corporate social responsibility. Performance, 13 (1), 73-82. http://journal.feb.unmul.ac.id/index.php/KINERJA/article/view/365

Haniffa, R. M., \& Cooke, T. E. (2005). The impact of culture and governance on corporate social reporting. Journal of accounting and public policy, 24(5), 391-430. https://doi.org/10.1016/j.jaccpubpol.2005.06.001

Herawati, Heti. 2015. Corporate Governance, Company Characteristics and Corporate Social Responsibility Disclosure. JRAP Accounting and Taxation Research Journal, Vol. 2, No. 2: 203-217. http://journal.univpancasila.ac.id/index.php/jrap/article/view/112 
Kamil, A., \& Herusetya, A. (2012). The influence of company characteristics on the extent of corporate social responsibility disclosure activities. Accounting Research Media, 2 (1). http://journal.bakrie.ac.id/index.php/journal_MRA/article/view/43

Kurniawan, Lydia. 2014. Various Factors That Influence Corporate Social Responsibility (CSR) in the Company's Annual Report. Jurnal Riset Akuntansi dan Auditing, Vol. 1, No. 1:16-34

Lanis, R., \& Richardson, G. (2012). Corporate social responsibility and tax aggressiveness: An empirical analysis. Journal of Accounting and Public Policy, 31(1), 86-108. https://doi.org/10.1016/j.jaccpubpol.2011.10.006

Muntoro, R. K. (2006). Building an Effective Board of Commissioners. Articles of the Management Institute of the Faculty of Economics, University of Indonesia. http://lmfeui.com/data/mui_Membangun\%20Dewan\%20Komisaris\%20\%20yang\%20Efektif_Ronny\%20K\%20Muntoro .pdf

Prakasa, S., \& Astika, I. B. P. (2017). Effect of Leverage, Profitability, and Management Ownership on Corporate Social Responsibility Disclosure of Mining Companies. E-Journal of Accounting, 189-215. https://ojs.unud.ac.id/index.php/Akuntansi/article/view/22487

Situmorang, R. (2018). Analysis of Factors Affecting Corporate Social Responsibility Disclosure of Consumer Goods Companies Registered in BEI 2014-2016 Period. http://repositori.usu.ac.id/handle/123456789/11749

Rahayu, I., \& Rahayu, D. F. (2013). Determinants of Social Responsibility Disclosure in Developing Countries: An Empirical Study of Manufacturing Companies in Indonesia. Exhibition, 8 (1). http://ejournal.uinsuka.ac.id/syariah/Ekbisi/article/view/342

Amalia, R., \& Utama, I. M. K. (2013). The Effect of Good Corporate Governance Indicators and Profitability on Corporate Social Responsibility Disclosures. E-Journal of Udayana University Accounting. Bali. https://ojs.unud.ac.id/index.php/Akuntansi/article/view/5515

Reverte, C. (2009). Determinants of corporate social responsibility disclosure ratings by Spanish listed firms. Journal of business ethics, 88(2), 351-366. doi:10.1006/bare.1997.0060

Richardson, V. J. (2000). Information asymmetry and earnings management: Some evidence. Review of quantitative finance and accounting, 15(4), 325-347. https://link.springer.com/article/10.1023/A:1012098407706

Santioso, Linda, dan Natasha Caesar Devona. 2012. Effect of Company Age, Company Size, Board of Commissioners, Leverage, and Profitability on Disclosure of Social Responsibility of Manufacturing Companies Registered in the Indonesia Stock Exchange 2008-2010. Jurnal Akuntansi, Volume 12, Nomor 1:595-616.

Sari, W. N., \& Rani, P. (2015). The Effect of Institutional Ownership, Managerial Ownership, Return on Assets (ROA) and Company Size on Disclosure of Corporate Social Responsibility (CSR) in Manufacturing Companies Listed on the Indonesia Stock Exchange Period 2011-2013. Journal of Accounting and Finance, 4 (1). https://journal.budiluhur.ac.id/index.php/akeu/article/view/392

Sembiring, Eddy Rismanda. 2005. Corporate Characteristics and Disclosure of Social Responsibility: Empirical Study of Companies Listed on the Jakarta Stock Exchange. SNA VIII. Solo, 15-16 September.

Sulistyawati, A. I., Surjanti, R., Setiasih, L. P. N., \& Triyani, D. (2016). Corporate Social Responsibility Disclosure of its Financial Statements and its Determination.

Wasito, G. A., Herwiyanti, E., \& Kusumastati, W. H. W. (2016). The effect of corporate governance, profitability, liquidity and solvency on corporate social responsibility disclosure. Journal of Business and Accounting, 18 (1), 1-10.

Yao, S., Wang, J., \& Song, L. (2011). Determinants of social responsibility disclosure by Chinese firms. The University of Nottingham-China Policy Institute. Discussion Paper, 72.

A book

Brennan, M. J. (1995). Corporate finance over the past 25 years. Financial Management, 9-22. https://www.jstor.org/stable/3665531

I. Ghozali, and A. Chariri, International Financial Reporting System Accounting Theory (IFRS), Semarang: Badan Penerbit Universitas Diponegoro, 2014. 